\title{
Chapter 20 \\ Design Procedure of a Hybrid Renewable Power Generation System
}

\author{
Seyed Vahid Hosseini, Ali Izadi, Seyed Hossein Madani, Yong Chen, \\ and Mahmoud Chizari
}

\begin{abstract}
Electrification of small communities in districted off-grid area remains as a challenge for power generation industries. In the current study, various aspects of design of a standalone renewable power plant are examined and implemented in a case study of a rural area in Cape Town, South Africa. Estimating required electricity based on local demand profile, investment, operability, and maintenance costs of different generation technologies are studied in order to investigate their potential in an off-grid clean energy generation system. Several configurations of hybridization of solar system, wind, and micro gas turbine in combination with a battery are investigated. The Levelized Cost of Electricity (LCOE) and number of days with more than $3 \mathrm{~h}$ black out are compared.
\end{abstract}

Keywords Hybrid power generation $\cdot$ Solar $\cdot$ Wind $\cdot$ Energy $\cdot$ Micro gas $\cdot$ Micro grid $\cdot$ Micro power plant

\subsection{Introduction}

Renewable systems have shown to have great potential to be employed in remote areas since they do not need expensive structure and complicated grid infrastructure [1]. A possible configuration for renewable generators and storages focusing on a combination of PV, wind, hydrogen fuel cell, battery, and pumped hydro is provided in [2]. While it is important to consider weather condition for the wind and solar generation in order to define optimal micro-grid operation [3].

Current article is prepared to address the first step to provide a procedure to evaluate the performance and economy of a hybrid renewable system with the required

S. V. Hosseini $(\bowtie) \cdot$ Y. Chen · M. Chizari

Univesity of Hertfordshire, Hatfield, UK

e-mail: v.hosseini@herts.ac.uk

A. Izadi · S. H. Madani

Samad-Power Ltd., Milton Keynes, UK

(C) The Author(s) 2021

I. Mporas et al. (eds.), Energy and Sustainable Futures, Springer Proceedings in Energy, https://doi.org/10.1007/978-3-030-63916-7_20 
battery capacity. A remote area in South Africa is chosen to compare various generation systems. Single source power plant with Wind, Solar PV and Micro Gas Turbine (MGT), as well as dual combination of these sources, are considered. Then it will be possible to optimize the hybridizing which will be reported in a separated article.

\subsection{Theory and Methodologies}

The required information for the analysis is mainly extracted from three different sources. (1) System Advisor Model (SAM) [4] which is an open source code developed by the National Renewable Energy Laboratory (NREL); (2) Photovoltaic Geographical information system [6] also provided by the European commission to extract solar energy; (3) The Global Atlas [5] provided by International Renewable Energy Agency to extract wind energy data.

For the MGTs (Micro gas turbines), characteristics of Capstone C35, C60 and C200S are considered. The wind energy assumed to be generated with a number of SAM generic $100 \mathrm{~kW}$ turbines. For the Solar PV, also, the solar library of SAM was deployed. The case study is demonstrated for a rural area near Cape Town. SAM software is utilized to calculate techno-economic parameters for each renewable energy generators. Both the demand and generation profile for the area is extracted in daily, monthly and annual manner.

\subsubsection{Profile Demand}

Total annual demand of the selected area is estimated to be around $1500 \mathrm{kWh}$ to supply 2500 people in a rural area using the World Bank [7] framework of South Africa plan. A similar profile demand in the SAM is normalized to meet this annual value. Since the case study is located in the southern hemisphere, more electricity is required from January to March and October to December for cooling purposes.

\subsubsection{Solar Power Generation}

Solar radiation data for the case study area is extracted from [8] then the Solar PV array is simulated using the SAM to supply the required demand. The monthly clearness index, defined as the fraction of solar radiation at the top of the atmosphere that reaches a particular location on the earth surface, is also considered varying between 0.495 (in August) and 0.586 (in October) with an annual average of 0.543. 


\subsubsection{Wind Power Generation}

The wind speed data for the case study location is obtained from the Global Wind Atlas (GWA). A wind farm with the NREL 100kW turbine, which is a reference turbine in the SAM, is selected to supply the load demand. The shear coefficient and hub height of this wind turbine are 0.14 and $80 \mathrm{~m}$, respectively. The hourly variation of the wind speed in the hub height is considered for the simulation.

\subsubsection{Micro Gas Turbine Power Generation}

According to market study considering site demands and the commercial micro gas turbine, Capstone C30, C65 and C200S are selected as the available MGT engines. Nominal characteristics of the each MGT is obtained from the Gas Turbine World magazine [9] and repair and maintenance of the MGTs is assumed to be $0.015 \$ / \mathrm{kWh}$. The effect of ambient condition on the performance of these engines is evaluated based on their correction curves [10]. Also, based on diesel wholesale price $(0.344$ $\$ /$ lit) and the heating values of $45.6 \mathrm{MJ} / \mathrm{kg}$ in South Africa, and the efficiency of MGTs, fuel cost is calculated to be $0.10,0.11$ and $0.13 \$ / \mathrm{kWh}$ for C200S, C65 and C30, respectively.

\subsubsection{Battery Pack Sizing}

The battery capacity is calculated in a way to cover the intermittency of the renewable sources in $24 \mathrm{~h}$ supply. To do so, the difference between demand load and power generation in the past $24 \mathrm{~h}$ of each hour for the whole year is calculated and the mode (charging/discharging) is determined. The accumulated of charging/discharging values within a duration defines the size of the battery pack.

\subsection{Financial Modelling}

To consider both capital and operating expenses (CAPEX and OPEX) for a generation system, 25 years lifetime is considered for the system. Based on available information, the current interest rate and inflation rate in Africa are $16 \%$ and $13.5 \%$ respectively [11] which results in $2.2 \%$ for the annual real interest rate. Moreover, to compare the economic aspect of the systems, it is assumed that the extra generation of the system could not be exported to the grid. 


\subsection{Results and Discussion}

This section investigates several configurations for utilization of the renewable sources for the case study area. At first step single power generator (solar PV or wind turbine or gas turbine) and then, the combination of power plants including two generators (Solar PV and Wind turbine, Solar PV and Gas turbine, wind turbine and gas turbine) with battery packs are simulated. Although the best share could be evaluated with optimization processes, shares of each power sources in this section are assessed in a heuristic manner with the target of obtaining a suitable fit on annual demand profile. Capacity of the power plant is adjusted to supply at least $90 \%$ of monthly demand load.

\subsubsection{Single Power Generation Plants}

A comparison between generations of the three single-source power plants which is plotted beside the monthly demand is shown in Fig. 20.1. As it could be seen, the MGT has the most uniform generation (due to less variation of the ambient condition of the site) and on the contrary, a Solar PV system to provide at least $90 \%$ of the demand, needs to be sized equivalent of two times of the annual demand. The worst $24 \mathrm{~h}$ of each generation system is plotted in Fig. 20.2. These graphs clearly show that for a PV system the daily difference between generation and demand profile is much higher in comparison with wind and MGT.

Besides the cost of electricity, sustainability of the generation is another important parameter in assessment of a plant. In this order, the number of days in which there is

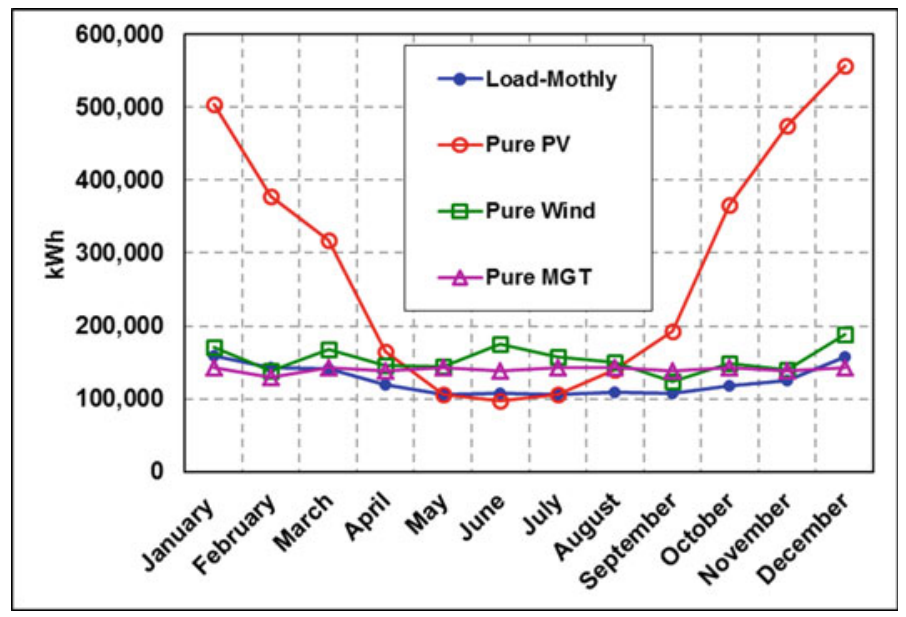

Fig. 20.1 Load versus Generation for single source power generation plants 


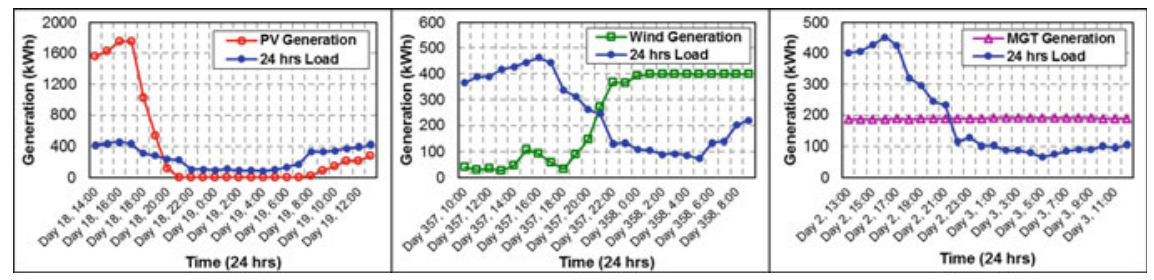

Fig. 20.2 Load versus Generation for worst $24 \mathrm{~h}$

Table 20.1 Comparison between single source power plants

\begin{tabular}{l|l|l|l|l}
\hline Techno-economic parameters & Solar & Wind & MGT \\
\hline \multirow{2}{*}{ Technical parameters } & Annual generation $(\mathrm{kWh})$ & $3,401,435$ & $1,850,304$ & $1,530,858$ \\
\cline { 2 - 5 } & Rating capacity $(\mathrm{kW})$ & 2680 & 400 & 200 \\
\cline { 2 - 5 } & Capacity factor $\%$ & 14.5 & 52.8 & 87.4 \\
\cline { 2 - 5 } & $\begin{array}{l}\text { Averaged generation per } \\
\text { month }(\mathrm{kWh})\end{array}$ & 279,570 & 154,192 & 127,571 \\
\cline { 2 - 5 } & $\begin{array}{l}\text { Averaged generation per } \\
\text { day }(\mathrm{kWh})\end{array}$ & 9,319 & 5,069 & 4,194 \\
\cline { 2 - 5 } & Battery capacity $(\mathrm{kWh})$ & 2,680 & 3239 & 1425 \\
\cline { 2 - 5 } & $\begin{array}{l}\text { Averaged extra generation } \\
\text { per day }(\mathrm{kWh})\end{array}$ & 5,189 & 960 & 85 \\
\cline { 2 - 5 } & $\begin{array}{l}\text { Days with more than } 3 \mathrm{~h} \text { of } \\
\text { no electricity access }\end{array}$ & 36 & 47 & 0 \\
\hline \multirow{2}{*}{ Economic parameter } & CAPEX $(\$)$ & $2,631,200$ & $1,280,000$ & 225,000 \\
\cline { 2 - 5 } & OPEX $(\$)$ & 22,770 & 8,000 & 163,000 \\
\cline { 2 - 5 } & LCOE $(\phi / \mathrm{kWh})$ & 18.7 & 8.9 & 12.1 \\
\hline
\end{tabular}

no supply for more than $3 \mathrm{~h}$ is indicated in Table 20.1. The wind power plant with the lowest value of LOCE has 47 days with more than $3 \mathrm{~h}$ completely off in contrary to MGT highest value of LOCE and no day in this condition. These results emphasize that hybridization could provide the possibility to enhance the overall outage of the plant.

\subsubsection{Hybrid Power Generation Plants}

To demonstrate the advantages of each generation system, results of combination of each two of them are presented in this section. Figure 20.3 shows both the monthly generation and monthly share of these hybrid systems in comparison with monthly demand. While the generation and demand profiles for a day with the worst condition 


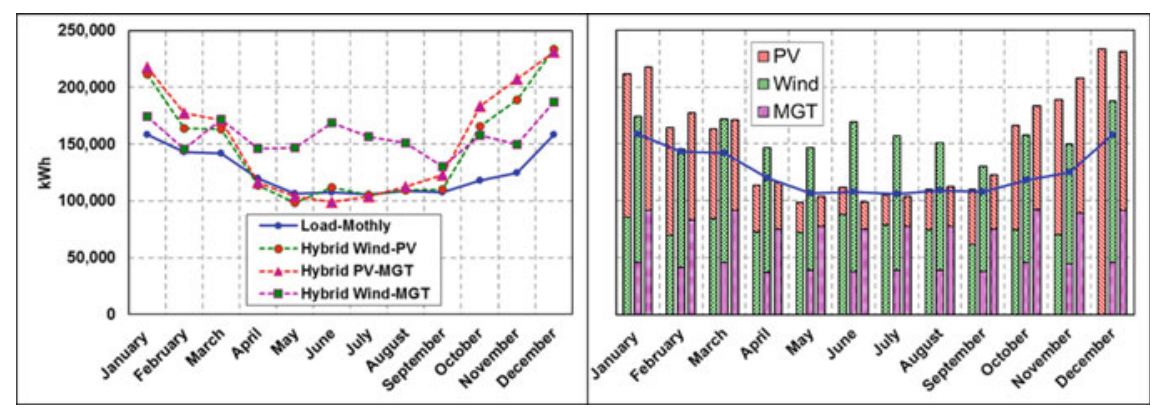

Fig. 20.3 Load versus Generation for hybrid power generation plants

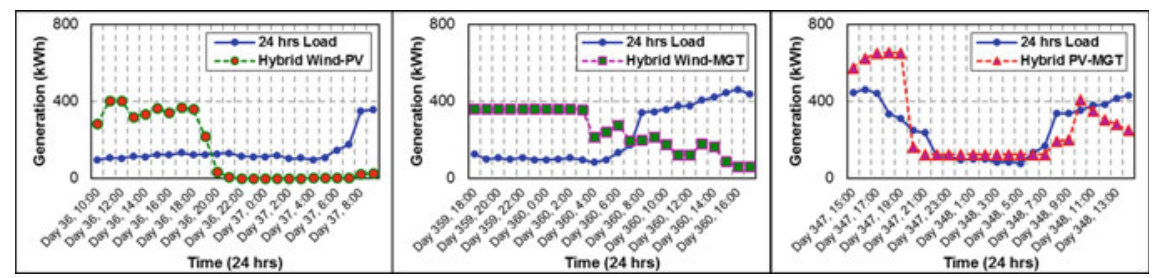

Fig. 20.4 Load versus Generation for worst $24 \mathrm{~h}$ of hybrid system

are used to size the battery which is plotted in Fig. 20.4. This condition occurs in January for the Wind-PV and in December for the other two systems.

Table 20.2 summarizes the overall techno-economic parameters of these systems. Hybridization has a great effect not only in reduction of LCOE of PV system but also in decreasing the number of days with more than $3 \mathrm{~h}$ of completely without generation. For the PV-Wind system, single PV and single wind, as shown in Table 20.1, there are 36 and 47 days in this condition, respectively; but the hybrid PV-Wind has only 25 days with more than 3 h completely without generation.

\subsection{Conclusion}

Solar PV which could provide at least $90 \%$ of monthly demand, generate twice the annual demand. By combination, the synchronization between generation and demand is enhanced. So, the Levelized Cost of Electricity is reduced. Moreover, to consider the quality of power generation, the number of days which have more than $3 \mathrm{~h}$ with completely no electricity is compared between different scenarios that show a noticeable improvement in combined systems. This study believes that optimization techniques considering various parameters are required to find the best solution for each case study. 
Table 20.2 Comparison between hybrid power plants

\begin{tabular}{|c|c|c|c|c|}
\hline \multicolumn{2}{|c|}{ Techno-economic parameters } & \multirow{2}{*}{$\begin{array}{l}\text { PV and Wind } \\
1,775,940 \\
\text { PV 48\% } \\
\text { Wind 52\% }\end{array}$} & \multirow{2}{*}{$\begin{array}{l}\text { Wind and MGT } \\
1,885,256 \\
\text { Wind } 74 \% \\
\text { MGT 26\% }\end{array}$} & \multirow{2}{*}{$\begin{array}{l}\text { PV and MGT } \\
1,845,845 \\
\text { PV 46\% } \\
\text { MGT 54\% }\end{array}$} \\
\hline $\begin{array}{l}\text { Technical } \\
\text { parameters }\end{array}$ & $\begin{array}{l}\text { Annual generation } \\
(\mathrm{kWh})\end{array}$ & & & \\
\hline & Rating capacity $(\mathrm{kW})$ & $\begin{array}{l}\text { PV: } 670 \\
\text { Wind: } 200\end{array}$ & $\begin{array}{l}\text { Wind: } 300 \\
\text { MGT: } 65\end{array}$ & $\begin{array}{l}\text { PV: } 650 \\
\text { MGT: } 2 \times 65\end{array}$ \\
\hline & Capacity factor $\%$ & 23 & 59 & 26 \\
\hline & $\begin{array}{l}\text { Averaged generation } \\
\text { per month }(\mathrm{kWh})\end{array}$ & 147,995 & 157,105 & 153,820 \\
\hline & $\begin{array}{l}\text { Averaged generation } \\
\text { per day }(\mathrm{kWh})\end{array}$ & 4,866 & 5,165 & 5,057 \\
\hline & $\begin{array}{l}\text { Battery capacity } \\
(\mathrm{kWh})\end{array}$ & 2,057 & 2,796 & 1,172 \\
\hline & $\begin{array}{l}\text { Averaged extra } \\
\text { generation per day } \\
(\mathrm{kWh})\end{array}$ & 756 & 1,055 & 947 \\
\hline & $\begin{array}{l}\text { Days with more than } \\
3 \text { h of no electricity } \\
\text { access }\end{array}$ & 25 & 0 & 0 \\
\hline \multirow{3}{*}{$\begin{array}{l}\text { Economic } \\
\text { parameter }\end{array}$} & CAPEX (\$) & $1,297,000$ & $1,060,000$ & 857,000 \\
\hline & OPEX (\$) & 9,693 & 64,000 & 121,693 \\
\hline & $\mathrm{LCOE}(\phi / \mathrm{kWh})$ & 9.1 & 11.2 & 13.7 \\
\hline
\end{tabular}

\section{References}

1. N. Izadyar, H.C. Ong, W.T. Chong, K.Y. Leong, Resource assessment of the renewable energy potential for a remote area: a review. Renew. Sustain. Energy Rev. 62, 908-923 (2016)

2. K.R. Khalilpour, A. Vassallo, A generic framework for distributed multi-generation and multistorage energy systems. Energy 114, 798-813 (2016)

3. W.D. Xu, Recent advance in energy management optimization for microgrid. IEEE Innovative Smart Grid Technologies e Asia (Isgt Asia) (2013)

4. V.A. Graham, K.G.T. Hollands, A method to generate synthetic hourly solar radiation globally. Sol. Energy 44(6), 333-341 (1990)

5. A.D. Duffie, W.A. Beckman, Solar Engineering of Thermal Processes, 4th edn. (Wiley, Hoboken, New Jersey, 2013).

6. M. Rohani, G. Nour, Techno-economical analysis of stand-alone hybrid renewable power system for Ras Musherib in United Arab Emirates. Energy 64, 828-41 (2014)

7. M. Bhatia, N. Angelou, Beyond Connections: Energy Access Redefined (World Bank, Washington, DC, 2015).

8. System Adviser Model (SAM), NREL (2018). https://sam.nrel.gov/

9. Gas Turbine Magazine,https://gasturbineworld.com/. Accessed November 2019

10. Capstone Model C65 Performance; Technical Reference, Capstone Turbine Corporation, Chatsworth, CA, USA (2008)

11. Trading Economics (2019). https://tradingeconomics.com/ghana/interest-rate 
Open Access This chapter is licensed under the terms of the Creative Commons Attribution 4.0 International License (http://creativecommons.org/licenses/by/4.0/), which permits use, sharing, adaptation, distribution and reproduction in any medium or format, as long as you give appropriate credit to the original author(s) and the source, provide a link to the Creative Commons license and indicate if changes were made.

The images or other third party material in this chapter are included in the chapter's Creative Commons license, unless indicated otherwise in a credit line to the material. If material is not included in the chapter's Creative Commons license and your intended use is not permitted by statutory regulation or exceeds the permitted use, you will need to obtain permission directly from the copyright holder.

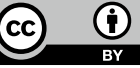

